\title{
PENGARUH STRATEGI PEMBELAJARAN KOPERATIF TIPE INVESTIGASI KELOMPOK TERHADAP HASIL BELAJAR SISWA KELAS XI SMAN 1 SINGARAJA \\ TAHUN 2013/2014
}

\author{
Oleh \\ Fransiskus Made Hariawan Citra \\ Jurusan Pendidikan Pancasila dan Kewarganegaran FIS UNDIKSHA
}

\begin{abstract}
ABSTRAK
Penelitian ini bertujuan untuk mengetahui perbedaan hasil belajar PKn antara siswa yang mengikuti dengan strategi pembelajaran kooperatif tipe investigasi kelompok dan siswa yang mengikuti pembelajaran dengan model pengajaran konvensional pada siswa kelas XI SMAN 1 Singaraja Kabupaten Buleleng tahun pelajaran 2013/2014.

Jenis penelitian ini adalah penelitian eksperimen semu. Populasi penelitian ini adalah seluruh siswa kelas XI SMAN 1 Singaraja Kabupaten Buleleng tahun pelajaran 2013/2014 yang berjumlah 255 orang. Sampel penelitian ini yaitu siswa kelas XI IA3 SMAN 1 yang berjumlah 30 orang dan siswa kelas XI IA4 SMAN 1 Singaraja yang berjumlah 30 orang. Data mengenai hasil belajar PKn siswa diperoleh melalui tes tertulis yang dilakukan pada akhir pembelajaran. Data yang diperoleh kemudian dikumpulkan dan dianalisis menggunakan analisis statistik deskriptif dan statistik inferensial (uji-t).

Berdasarkan hasil analisis data, diperoleh $t_{\text {hit }}=13,20$ dan $t_{\text {tab }}$ (pada taraf signifikansi 5\%) $=2,00$. Hal ini berarti bahwa $t_{\text {hit }}>t_{t a b}$, sehingga dapat diinterpretasikan bahwa terdapat perbedaan hasil belajar PKn yang signifikan antara siswa yang mengikuti pembelajaran dengan model discovery learning dan siswa yang mengikuti pembelajaran dengan model pengajaran langsung. Diperoleh rata-rata $(\bar{X})$ hitung, kelompok eksperimen adalah 26,9 dan kelompok kontrol adalah 16,73. Hal ini berarti bahwa $\bar{X}$ eksperimen $>\bar{X}$ kontrol, sehingga dapat disimpulkan bahwa model pembelajaran Discovery learning berpengaruh terhadap hasil belajar PKn siswa kelas XI SMAN 1 Singaraja kabupaten Buleleng
\end{abstract}

Kata-kata kunci: strategi pembelajaran kooperatif tipe investigasi kelompok, hasil belajar PKn

\begin{abstract}
This study aims to determine the differences in learning outcomes between students who take the Civics with cooperative learning strategies and investigations group of students who take lessons with conventional teaching model in class XI students of SMAN 1 Singaraja Buleleng academic year 2013/2014.
\end{abstract}

This research is a quasi experimental study. The study populationwas all students of class XI of SMAN 1 Singaraja Buleleng academic year 2013/2014, amounting to 255 people . The study sample is a class XI student of SMAN 1 IA3 which were 30 students of class XI and IA4 SMAN 1 Singaraja totaling 30 people . Data on students' learning outcomes Civics obtained 
through a written test conducted at the end of the lesson. The data obtained were then collected and analyzed using descriptive statistical analysis and inferential statistics (test ).

Based on the analysis of data, obtained thit $=13.20$ and ttab ( at significance level of 5 $\%)=2.00$. This means that thit $>$ ttab, so that it can be interpreted that there are differences in learning outcomes between students Civics significant that follows the model of learning with group investigastion and the learning of students who take the direct teaching model . Obtained average $(\bar{X})$ count, the experimental group was 26.9 and the control group was 16.73 . This means that the experimental > control, so it can be concluded that the model of learning group investigastion affect learning outcomes Civics class XI students of SMAN 1 Singaraja regency of Buleleng.

Key words : cooperative learning strategy group investigation, the results of studying Civics.

\section{PENDAHULUAN}

Di era globalisasi, dengan kemajuan IPTEK yang sangat pesat kita dituntut untuk memahami lebih dalam tentang jati diri sebagai warga Negara dalam kehidupan berbangsa dan bernegara. Setiap warga Negara, dituntut untuk dapat hidup berguna dan bermakna bagi Negara dan bangsanya serta mampu mengantisipasi perkembangan dan perubahan masa depannya. Harapan ini, tertumpu pada mata pelajaran pendidikan kewarganegaraan yang memiliki tujuan utama " untuk menumbuhkan wawasan dan kesadaran bernegara,serta membentuk sikap dan perilaku cinta tanah air yang bersendikan kebudayaan bangsa". (Endang, 2002:2).

Untuk membentuk warga Negara yang baik memahami, menghayati, serta mengamalkan hak dan kewajibannya sebagai warga Negara,maka dalam pendidikan formal di sekolah wajib di berikan pendidikan kewarganegaraan. Pendidikan pada hakikatnya, berlangsung dalam suatu proses. Proses tersebut berupa transformasi, nilai-nilai, pengetahuan, teknologi, dan keterampilan. Dalam proses belajar-mengajar, yang menerima proses pembelajaran adalah siswa yang sedang tumbuh dan berkembang menuju arah pendewasaan kepribadian dan penguasaan pengetahuan ( Arsjad dan Mukti,1991:12). seiring dengan hal itu,kurikulum tingkat satuan pendidikan (KTSP) yang berlaku sekarang ini,pembelajaran lebih berpusat pada siswa. Hal ini bearti,dalam suatu proses pembelajaran siswa di tuntut lebih aktif dari pada guru. Dalam konsep KTSP yang seperti itu,pembelajaran kewarganegaraan di kembangkan agar siswa yang menguasai keterampilan mengemukakan pendapat, memecahkan permasalahan, menyatukan perbedaan pendapat, untuk mencapai kesepakatan.

Salah satu model yang di anjurkan oleh KTSP adal model pembelajaran kooperatif yang memilki ati dan makna bekerja sama dalam mencapai tujuan yang sama. Pembelajaran kooperatif lebih mentik beratkan pada proses belajar pada kelompok-kelompok kecil,di mana siswa bekerja sama belajar satu sama lain,berdiskusi dan saling berbagi ilmu pengetahuan, saling berkomunikasi, saling membantu untuk memahami materi pelajaran.

Hal ini,tersurat dalam pasal 27 Undang-Undang Republik Indonesia No. 20 tahun 2003 tentang Sistim Pendidikan Nasional (SIKDIKNAS) yang menyebut bahwa : (1) Kurikulum pendidikan dasar dan menengah wajib memuat: (a) Pendidikan agama, (B) pendidikan kewarganegaraan, (c) Bahasa, (d) Matematika, (e) IImu Pengetahuan Alam, (f) Ilmu Pengetahuan sosial, (g) Seni dan Budaya, (h) Pendidikan Jasmani dan Olahraga, (i) keterampilan/Kejuruan, (j) Muatan lokal. (2) Kurikulum Pendidikan 
Tinggi Wajib memuat: (a) Pendidikan Agama, (b) Pendidikan Kewarganegaran, (c) Bahasa.

Selain itu Guru pembimbing harus mengatur strategi pengajarannya yang sesuai dengan gaya-gaya belajar anak didik, biasanya permasalahan yang guru hadapi ketika berhadapan dengan sejumblah anak didik adalah masalah dalam pengelolan kelas juga merupakan disiplin. Peran guru, paling tidak berusaha mengatur suasana kelas yang kondusif bagi kegairahan dan kesenangan belajar anak didik,untuk memicu kesiapan siswa yang akan menunjukan kedisiplinanya dalam proses belajar PKn.

Berdasarkan hasil observasi yang dilakukan di SMA Negeri 1 Singaraja KabupatenBuleleng, proses kegiatan pembelajaran di kelas Xlkhususnya pada mata pelajaran PKn masih besifat sederhana, dimana guru hanya mengandalkan metode ceramah dalam menyampaikan suatu materi pelajaran. Padahal, ilmu pengetahuan sosial sangat menuntut adanya media atau model pembelajaran yang tepat. Digunakan pada saat kegiatan pembelajaran berlangsung guna mengembangkan kemampuan berpikir siswa. Namun, kenyataannya di lapangan bahwa guru tidak mengupayakan pengadaan sarana dan prasarana yang lengkap yang dapat menunjang kegiatan belajar mengajar.

Untuk mengatasi hal tersebut, penulis melakukan penelitian yang berjudul Pengaruh strategi pembelajaran kooperatif tipe investigasi kelopok siswa terhadap hasil belajar di kelasXI SMA Negeri 1 Singaraja tahun 2012/2013.

Nilai siswa di kelas XI masih berada di bawah kriteria ketuntasan minimal (KKM) yaitu 78,00,yang seharusnya nilai standar ketuntasan minimal sebesar 81,00.menurut guru, saat proses pembelajaran berlangsung, siswa lebih banyak memilih berdiam diri dari pada mengemukan pendapat pada hal,mengemukakan pendapat merupakan dasar untuk membangun. "Proses bahwa siswa secara aktif membangun atau membuat pengetahuannya sendiri dan realitas ditentukan oleh pengalaman orang itu sendiri pula" (Soli, 2009:26). Seperti yang di ketahui bersama siswa di kelas XI juga bermain-main laptop ataupun mengobrol saat pelajaran berlangsung dan ada pula yang mengantuk.

Hal-hal tersebut mengakibatkan siswa tidak dapat merespon dengan baik hal yang disampaikan oleh guru. pada hal itu, sangat penting dan harus di kuasai. Dengan penerapan strategi pembelajaran kopertif tipe investigasi kelompok, diharapkan dapat memperbaiki dan mengatasi proses pembelajaran pada mata pelajaran PKn. Sehingga, siswa dapat mengembangkan kemampuan berpikir kritis dan kreatif, serta mampu mengembangkan pengetahuannya sendiri.

Dengan demikian, strategi pembelajaran kooperatif tipe investigasi kelompok dapat memberikan pengalaman dan pembelajaran yang bermakna bagi siswa. Solusi yang di tawarkan untuk mencapai hasil belajar PKn, yaitu peneliti mecoba menawarkan strategi pembelajaran kooperatif tipe investigasi kelompok yang dianggap pembelajaran ini siswa dapat menemukan sendiri materi pembelajaran di kelas dari pengalaman yang di dapatkan apakah dari membaca Koran, buku, internet, dan lain-lain.

Selain itu, keunggulan strategi pembelajaran kooperatif tipe investigasi kelompok menurut (Roestiyah,2001: 4), yaitu" (1) Teknik ini mampu membantu siswa untuk mengembangkan, memperbanyak kesiapan, serta penguasaan keterampilan dalam proses kognitif/pengenalan siswa. (2) Siswa memperoleh pengetahuan yang bersifat sangat pribadi/individual sehingga dapat kokoh atau mendalam tertinggal dalam jiwa siswa tersebut. (3) Dapat meningkatkan kegairahan belajar para siswa.

Adapun penelitian yang relevan yang mempergunakan model pembelajaran kooperatif tipe investigasi kelompok yaitu di lakukan oleh I Wayan Miyasa, pada tahun 
2011 dengan judul "Penerapan model pembelajaran kooperatif tipe group investigation (GI) berbantu media gambar untuk meningkatkan efektifitas proses pembelajaran dalam mata pelajaran PKn pada siswa kelas XI SMA Negeri 1 Sukasada tahun Ajaran 2010/2011". Hasil penelitian tersebut menunjukan bahwa penerapan model pembelajaran kooperatif tipe investigasi kelompok dapat meningkatkan hasil belajar dan kualitas proses pembelajaran PKn siswa.

Berdasarkan paparan tersebut diatas, di harapkan implementasi strategi pembelajaran koopratif tipe investigasi kelompok dapat meningkat hasil belajar PKn pada siswa di kelas XI SMA Negeri 1 Singaraja tahun 2012/213.

Pedidikan Kewarganegaraan (PKn) merupakan upaya untuk membentuk warga Negara yang baik dalam kehidupan bermasyarakat berbangsa dan bernegara Dengan pembelajaran Pendidikan Kewraganegaraan (PKn) yang tersebut diatas, maka pemerintah melalui UU No 2 Tahun 2003 tentang Sistem Pendidikan Nasional menetapkan bahwa pendidikan kewarganegaraan sebagai mata pelajaran wajib dari tingkat Sekolah Dasar (SD), sampai Sekolah Menengah Atas (SMA).

\section{METODE}

Penelitian ini dilakukan pada sekolah dasar gugus 5 Kecamatan Kediri khususnya kelas $\mathrm{V}$, melibatkan sebanyak 9 kelas sebagai populasi penelitian dan 2 kelas sebagai sampel penelitian. Sebelum penarikan sampel dilakukan maka diadakan uji kesetraan. Berdasarkan hasil uji kesetaraan yang dilakuan pada 8 kelas populasi menunjukkan $F_{\text {hitung }}$ sebesar 0,014 dan $F_{\text {tabel }} 1,92$ dengan taraf signifikasi $5 \%$. Hal ini berarti bahwa Fhitung < Ftabel, sehingga seluruh populasi sudah setara.

Penentuan sampel penelitian ini menggunakan teknik random sampling. Seluruh kelas yang ada akan dirandom untuk menentukan dua kelas sebagai sampel penelitian. Kelas yang muncul sebagai sampel penelitian yaitu Kelas XI IA
3 dan Kelas XI IA 4 SMAN 1 Singaraja. Kemudian kedua kelas sampel ini dirandom kembali untuk mendapatkan kelas kontrol yang menggunakan model pembelajaran konvensional dan kelas eksperimen yang menggunakan Pembelajaran kooperatif tipe investigasi kelompok. Adapun kelas yang mendapat perlakuan Pembelajaran kooperatif tipe investigasi kelompok adalah kelas XI IA 3 dan yang mendapat perlakuan motode pembelajaran konvensional adalah kelas XI IA 4. Jumlah keseluruhan sampel yang digunakan sebanyak 2 kelas.

Desain penelitian ini menggunakan posttest only non-equivalent control group design.

$\begin{array}{lll}\text { Eksperimen } & \mathrm{X}_{1} & \mathrm{O}_{1}\end{array}$

Kontrol

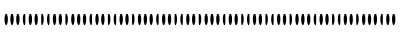

$$
\begin{array}{ll}
\mathrm{X}_{2} & \mathrm{O}_{2}
\end{array}
$$

Gambar 1. Posttest Only Non-Equivalent Control Group Design

(diadaptasi dari Sugiyono, 2009)

Keterangan

$\mathrm{X}_{1}$ : Pengamatan kemampuan berpikir kritis kelompok eksperimen.

$\mathrm{X}_{2}$ : Pengamatan kemampuan berpikir kritis kelompok kontrol.

$\mathrm{O}_{1}$ : Perlakuan 1, pembelajaran kooperatif tipe investigasi kelompok pada kelompok eksperimen.

$\mathrm{O}_{2}$ : Perlakuan 2, model pembelajaran konvensional pada kelompok kontrol.

Variabel dalam penelitian meliputi variabel bebas dan variabel terikat. Variabel bebasnya yaitu pembelajaran kooperatif tipe investigasi sedangkan variabel terikatnya yaitu kemampuan berpikir kritis. Instrumen penelitian menggunak tes kemampuan berpikir kritis berupa tes esaay. Instrumen penelitian di adaptasi dari 6 indikator berpikir kritis yang dijabarkan oleh Arnyana (dalam Purnomo, 2011) yang meliputi 6 indikator berpikir kritis diantaranya: (1) merumuskan masalah, (2) memberikan argumen, (3) melakukan deduksi, (4) melakukan induksi, 
melakukan evaluasi, keputusan dan tindakan.

(6) mengambil

Untuk menguji kelayakan instrumen penelitian maka perlu dilakukan pengujian instrumen yang meliputi: (1) uji validitas menggunakan rumus product moment karena soal bersifat politomi, (2) reliabilitas menggunakan rumus Alpha-Cronbach, (3) tingkat kesukaran test. Berdasarkan hasil pengujian instrumen maka diperoleh 20 soal essay yang dipergunakan untuk tes akhir (post test). Data dianalisis menggunakan teknik analisis deskriptif dan analisis inferensial. Teknik analisis deskriptif meliputi analiisi mean, median, modus dan standar deviasi. Analisis inferensial meliputi: (1) uji normalis menggunakan rumus Chi-square, (2) uji homogenitas menggunakan rumus uji Fisher (uji F) dan (3) uji hipotesis menggunakan rumus uji $t$ sampel tak berkorelasi polled varians, rumus ini dipilih karena data berdistribusi normal, homogen dan jumlah sampel antara kedua kelompok berbeda. Untuk mempermudah menganlisis data, maka data dianalisis menggunakan bantuan pengelolah angka Microsoft Office Excel 2007.

\section{HASIL DAN PEMBAHASAN HASIL}

Deskripsi data kemampuan berpikir kritis kelompok eksperimen dan kelompok kontrol disajikan pada Tabel 1 berikut.

Tabel 1. Deskripsi Data Kemampuan Berpikir Kritis Kelompok Eksperimen dan Kontol

\begin{tabular}{lcc}
\hline \hline Statistik & Kelompok Eksperimen & Kelompok Kontrol \\
\hline Mean & 26,90 & 16,73 \\
Median & 27,25 & 16,15 \\
Modus & 27,75 & 15,49 \\
Standar deviasi & 4,68 & 3,73 \\
Varian & 21,97 & 13,94 \\
\hline
\end{tabular}

Berdasarkan data pada Tabel 1, maka data kemampuan berpikir kritis kelompok eksperimen dan kontrol dapat disajikan dalam bentuk grafik seperti Gambar 2 berikut.

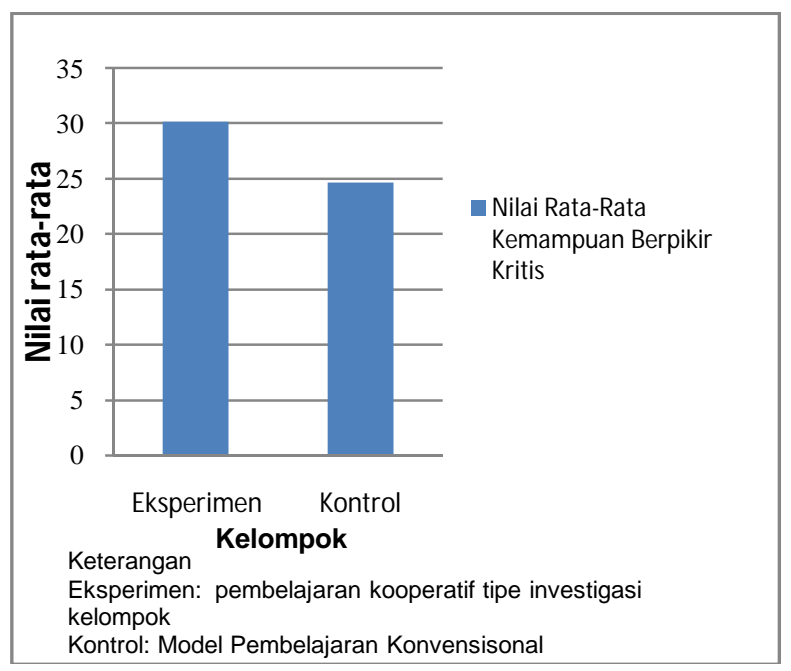

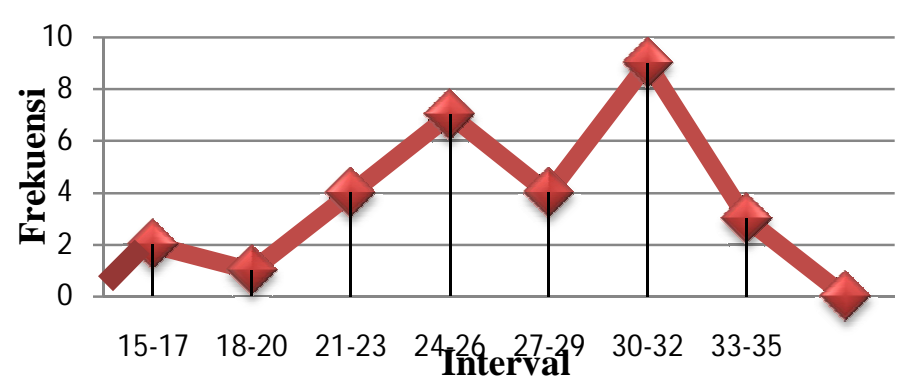

Data kemampuan berpikir kritis kelompok eksperimen dapat disajikan ke dalam bentuk kurva poligon seperti pada Gambar 3 sebagai berikut.

Berdasarkan hasil perhitungan mean median dan modus serta poligon di atas, menunjukkan bahwa harga statistik Mo > Md > M (26,90>27,25>27,75). Berdasarkan gambar tersebut dapat diinterpretasikan bahwa kebanyakan skor kemampuan 
berpikir kritis $\mathrm{PKn}$ cenderung tinggi dan kurva juling negatif.

Data kemampuan berpikir kritis kelompok kontrol dapat disajikan ke dalam bentuk kurva poligon seperti pada Gambar 4 sebagai berikut.

Skor mean (M), Median (Me), Modus (Mo) digambarkan dalam grafik.

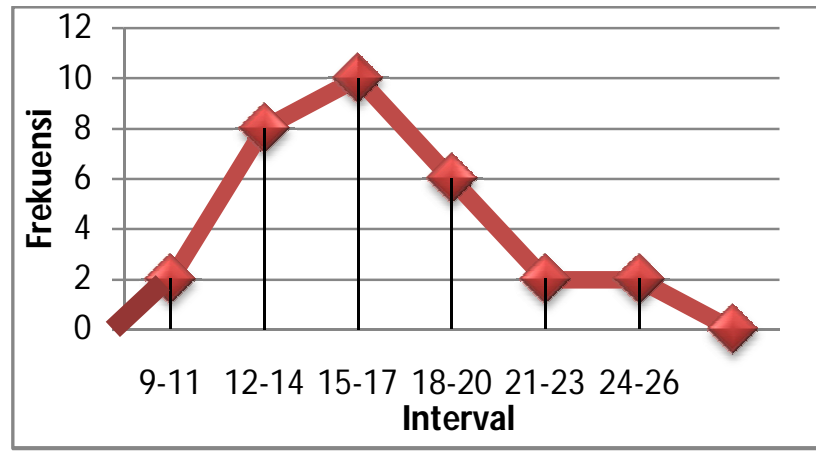

Skor mean (M), Median (Me), Modus (Mo) digambarkan dalam grafik.

Gambar 4. Polygon Data Kemampuan

Berpikir Kritis Kelompok Kontrol

Berdasarkan hasil perhitungan mean, median dan modus serta poligon di atas, menunjukkan bahwa harga statistik Mo< $\mathrm{Md}<\mathrm{M}(16,73<16,15<15,49)$. Berdasarkan gambar tersebut dapat diinterpretasikan bahwa kebanyakan skor kemampuan berpikir kritis PKn cenderung rendah dan kurva juling positif.

Data kemampuan berpikir kritis kemudian dikonversikan pada pedoman konversi skala lima kemampuan berpikir kritis sebagai berikut.

Tabel 2. Pedoman Konversi Kemampuan Berpikir Kritis Kelompok Eksperimen dan Kontol

\begin{tabular}{ll}
\hline \hline Rentang Skor & Kategori \\
\hline $30 \leq X<40$ & Sangat tinggi \\
$23 \leq X<30$ & Tinggi \\
$17 \leq X<23$ & Sedang \\
$10 \leq X<17$ & Rendah \\
$0 \leq X<10$ & Sangat rendah \\
\hline
\end{tabular}

(dimodifikasi dari koyan, 2011)

Berdasarkan Tabel 2 nilai rata-rata kelompok eksperimen sebesar 26,90 maka nilai rata-rata kelompok eksperimen dikategorikan sangat tinggi. Nilai rata-rata kelompok kontrol adalah 16,73 maka nilai rata-rata kelompok kontrol dikategorikan tinggi.

Berdasarkan hasil uji prasyarat menunjukkan bahwa data bersistribusi normal dan homogen, maka pengujian hipotesis dapat dilakukan dengan uji-t. Hipotesis penelitian yang diuji adalah terdapat perbedaan yang signifikan antara kemampuan berpikir kritis PKn siswa yang menggunakan pembelajaran kooperatif tipe investigasi kelompok dan siswa yang menggunakan pembelajaran konvensional. Untuk menguji hipotesis yang diajukan digunakan uji-t independent "sampel tak berkorelasi".

Kriteria pengujian adalah tolak $\mathrm{H}_{0}$ jika $t$ hitung $>t$ tabel, dimana $t$ tabel diperoleh dari tabel distribusi $t$ pada taraf signifikansi $5 \%$ dengan derajat kebebasan $\mathrm{db}=\mathrm{n}_{1}+\mathrm{n}_{2}-2$. Rangkuman hasil analisis uji-t ditunjukkan pada Tabel 5 sebagai berikut.

Tabel 3. Rangkuman Hasil Uji-t 


\begin{tabular}{lcccccc}
\hline \hline Kelompok & $\mathbf{N}$ & $\mathbf{D b}$ & $\overline{\mathrm{X}}$ & $\mathbf{S}$ & $\mathbf{t}_{\text {hitung }}$ & $\mathbf{t}_{\text {tabel }}$ \\
\hline Eksperimen & 30 & 4 & 26,90 & 4,68 & & \\
Kontrol & 30 & 3 & 16,73 & 3,73 & & 2,00 \\
\hline
\end{tabular}

Berdasarkan kriteria pengujian, karena $t_{\text {hitung }}>t_{\text {tabel }}$ maka Ho ditolak dan $\mathrm{Ha}$ diterima. Artinya terdapat perbedaan yang signifikan kemampuan berpikir kritis $\mathrm{PKn}$ antara siswa yang menggunakan pembelajaran kooperatif tipe investigasi dengan siswa menggunakan pembelajaran konvensional siswa kelas XI SMAN 1 Singaraja.

\section{PEMBAHASAN}

Berdasarkan hasil analisis data yang telah dilakukan menunjukkan bahwa kemamuan berpikir kritis kelompok eksperimen lebih baik dibandingkan kelompok kontrol. Pembahasan hasil-hasil penelitian dan pengujian hipotesis menyangkut tentang hasil belajar PKn siswa pada kelompok eksperimen dan kelompok kontrol.

Strategi pembelajaran kooperatif tipe investigasi kelompok yang diterapkan pada kelompok eksperimen dan model pembelajaran konvensional yang diterapkan pada kelompok kontrol dalam penelitian ini menunjukkan pengaruh yang berbeda pada hasil belajar PKn siswa. Hal ini dapat dilihat darihasil belajar PKn siswa. Secara deskriptif, hasil belajar PKn siswa kelompok eksperimen lebih tinggi dibandingkan dengan siswa kelompok kontrol. Tinjauan ini didasarkan pada ratarata skor hasil belajar PKn dan kecenderungan skor hasil belajar PKn. Rata-rata skor hasil belajar PKn siswa kelompok eksperimen adalah 26,90 berada pada katagori tinggi sedangkan skor hasil belajar PKn siswa kelompok kontrol adalah 16,73 berada pada katagori rendah.

Jika skor hasil belajar PKn siswa kelompok eksperimen digambarkan dalam grafik poligon tampak bahwa kurve sebaran data merupakan juling negatif yang artinya sebagian besar skor siswa cenderung tinggi. Pada kelompok kontrol, jika skor hasil belajar PKn siswa digambarkan dalam grafik poligon tampak bahwa kurve sebaran data merupakan juling positif yang artinya sebagian besar skor siswa cenderung rendah.

Berdasarkan analisis data menggunakan uji-t yang ditunjukkan pada Tabel 4.8 diketahui $t_{\text {hitung }}=13,20$ dan $t_{\text {tabel }}$ $(\mathrm{db}=$ dan taraf signifikansi $5 \%)=2,0058$. Hasil perhitungan tersebut menunjukkan bahwa $t_{\text {hitung }}$ lebih besar dari $t_{\text {tabel }}$ ( $t_{\text {hitung }}>$ $\left.t_{\text {tabel }}\right)$ sehingga hasil penelitian adalah signifikan. Hal ini berarti, terdapat perbedaan hasil belajar PKn yang signifikan antara siswa yang mengikuti dengan menggunakan strategi pembelajaran kooperatif tipe investigasi kelompok dan siswa yang mengikuti pembelajaran dengan model pembelajaran konvensional pada siswa kelas XI semester Ganjil tahun ajaran 2013/2014 di SMAN 1 Singaraja.Adanya perbedaan yang signifikan menunjukkan bahwa pembelajaran dengan strategi pembelajaran kooperatif tipe investigasi kelompokberpengaruh terhadap hasil belajar PKn siswa.

Perbedaan hasil belajar yang signifikan antara siswa yang mengikuti pembelajaran dengan strategi pembelajaran kooperatif tipe investigasi kelompok dan siswa yang mengikuti pembelajaran dengan model pembelajaran konvensional disebabkan karena perbedaan perlakuan pada langkahlangkah pembelajaran dan proses penyampaian materi. Pembelajaran dengan Strategi kooperatif tipe investigasi kelompok menekankan aktivitas guru dan siswa melalui langkah-langkah, yaitu: assurance (percaya diri), relevance (relevansi), interest (minat/perhatian), assisment (evaluasi), dan satisfaction (penguatan).

Pada tahap assurance (percaya diri), siswa dituntun untuk menyadari kekuatan dan kelemahan dirinya, serta gambaran diri positif terhadap diri sendiri. Siswa diberikan tugas dimulai dari yang mudah berangsur sampai ke tugas yang sukar. Menyajikan materi secara bertahap 
sesuai dengan urutan dan tingkat kesukarannya merupakan salah satu usaha menanamkan rasa percaya diri pada siswa.

Setelah tahap assurance (percaya diri) dilanjutkan dengan tahap relevance (relvansi). Pada tahap ini, siswa akan mengetahui tujuan sasaran yang akan dicapai serta manfaat pelajaran bagi kehidupan siswa baik untuk masa sekarang dan/atau untuk berbagai aktivitas di masa mendatang. Hal tersebut sesuai dengan pendapat Keller (dalam Zulfarisna, 2009:39) bahwa "siswa akan terdorong mempelajari sesuatu kalau apa yang akan dipelajari ada relevansinya dengan kehidupan mereka dan memiliki tujuan yang jelas".

Setelah tahap relevance (relvansi) kemudian tahap interest(minat/perhatian). Pada tahap ini siswa diberikan kesempatan untuk berpartisipasi secara aktif dalam pembelajaran, misalnya para siswa diajak diskusi untuk memilih topik yang akan dibicarakan, mengajukan pertanyaan atau mengemukakan masalah yang perlu dipecahkan, demonstrasi dan simulasi yang dapat dilakukan untuk menarik minat/perhatian siswa. Dengan adanya minat/perhatian siswa maka pembelajaran akan berjalan baik. Hal tesebut diperkuat oleh prinsip belajar menurut Gestalt (dalam Riyanto, 2010:65) bahwa "belajar lebih berhasil bila dengan minat, keinginan dan tujuan siswa".

Setelah tahap interest

(minat/perhatian) kemudian tahap assessment (evaluasi). Pada tahap ini evaluasi tidak hanya dilakukan oleh guru tetapi juga oleh siswa untuk mengevaluasi diri mereka sendiri (self assessment) atau evaluasi diri. Evaluasi diri dilakukan oleh siswa terhadap diri mereka sendiri, maupun terhadap teman mereka. Hal ini akan mendorong siswa untuk berusaha lebih baik lagi dari sebelumnya agar mencapai hasil yang maksimal.

Setelah assessment (evaluasi) barulah beranjak pada tahap yang terakhir yaitu tahap satisfaction (penguatan). Pada tahap ini siswa bersama guru menarik kesimpulan dan merangkum materi yang telah dipelajari,siswa diberikan perhatian yang besar oleh guru, sehingga mereka merasa dikenal dan dihargai oleh para guru. Menurut Slameto (dalam Riyanto,
2010:63) "belajar harus dapat menimbulkan reinforcement (penguatan) dan motivasi yang kuat pada siswa untuk mencapai tujuan instruksional".

Berdasarkan langkah-langkah strategi pembelajaran kooperatif tipe investigasi kelompok yang dilakukan saat penenlitian, terlihat bahwa guru dalam pembelajaran memposisikan diri sebagai mediator dan fasilitator. Siswa diarahkan untuk melakukan kegiatan belajarnya secara inkuiri ilmiah (scientific inquiry) dan konstruktivis sehingga siswa aktif mengkonstruksi pengetahuannya sendiri. Selain itu, siswa dibiasakan untuk memiliki rasa yakin/percaya diri yang nantinya dapat menubuhkan rasa bangga melalui kegiatan pembelajaran yang memiliki relevansi dengan kehidupan siswa, sehingga siswa tertarik. Dengan begitu minat/perhatian siswapun terfokus pada pembelajaran.

Berbeda halnya dalam pembelajaran dengan model konvensional yang hanya berpusat pada guru sehingga membuat siswa kurang aktif dalam pembelajaran. model pembelajaran konvensional ini merupakan model yang paling sederhana yang sebagian besar digunakan oleh guru. penyampaian materi dalam pembelajaran konvensional tersebut lebih banyak dilakukan melalui metode ceramah, tanya jawab, serta penugasan yang berlangsung secara terus menerus. Dalam penelitian ini, guru lebih banyak mendominasi kegiatan pembelajaran. Siswa berperan sebagai pendengar yang pasif dan mengerjakan apa yang disuruh guru serta melakukannya sesuai dengan yang dicontohkan. Antar siswa sangat jarang terjadi interaksi. Selain itu dalam pembelajaran siswa sering menghapal pengertian dan contoh-contoh dalam buku. Siswa kesulitan dalam mencari contoh dalam kehidupannya sehari-hari.

Perbedaan cara pembelajaran antara pembelajaran dengan strategi pembelajaran kooperatif tipe investigasi kelompok dan pembelajaran dengan model pembelajaran konvensional tentunya akan memberikan dampak yang berbeda pula terhadap hasil belajar siswa.Pembelajaran dengan strategipembelajaran kooperatif tipe investigasi kelompokmemungkinkan siswa untuk tahu manfaat dari materi yang 
dipelajari bagi kehidupannya, aktif dalam kegiatan pembelajaran, menemukan sendiri konsep-konsep yang dipelajari tanpa harus selalu tergantung pada guru, mampu memecahkan masalah-masalah yang berkaitan dengan konsep yang dipelajari, bekerja sama dengan siswa lain, dan berani untuk mengemukakan pendapat. Siswa menjadi lebih tertantang untuk belajar dan berusaha menyelesaikan semua permasalahan PKn yang ditemui, sehingga pengetahuan yang diperoleh akan lebih diingat oleh siswa. Dengan demikian, hasil belajar PKn siswa yang diajar dengan strategi pembelajaran kooperatif tipe investigasi kelompok akan lebih baik dibandingkan dengan siswa yang diajar dengan model konvensional.

Hasil penelitian ini sejalan dengan hasil dari beberapa penelitian tentang penerapan model pembelajaran kooperatif tipe investigasi kelompok.Zufarisna (2009) mengadakan penelitian yang menggunakan model pembelajaran investigasi kelompokyang berjudul "Penggunaan model ini Untuk Meningkatkan aktifitas dan Hasil Belajar PKn Siswa Kelas XI I.A5 SMA Negeri 1 Padang Panjang Pada Kopetensi Fungsi Komposisi". Hasil penelitian ini menunjukkan bahwa pembelajaran PKn dengan model kooperatif tipe investigasi kelompok dapat membantu guru dan siswa untuk meningkatkan keaktifan siswa, rasa percaya diri siswa sehingga mereka termotivasi untuk mencapai suatu keberhasilan serta keterampilan siswa dalam mengambil kesimpulan lebih bagus dibandingkan sebelumnya. Sehingga patut kiranya model pembelajaran kooperatif tipe investigsi kelompok dapat diterapkan mata pelajaran $\mathrm{PKn}$ sebagai alternatif dari metode yang di gunakan dalam proses pembelajaran.

Utami (2011) melakukan penelitian yang menggunakan model pembelajaran koperatif tipe investigasi kelompok yang berjudul "Implementasi Model Pembelajaran kooperatif tipe investigasi kelompok Berbantuan Media LCD dan power point dalam diskusi kelompok. Untuk Meningkatkan Keaktifan dan Prestasi Belajar Mata Pelajaran PKn. Pada Siswa Kelas XI Semester I Tahun Ajaran 2010/2011 di SMAN 2 Singaraja Kabupaten
Buleleng". Subyek penelitian ini adalah Siswa kelas X SMAN 2 Singaraja. Jumlah siswa yang terlibat sebagai subyek sasaran dalam penelitian ini adalah 30 orang. Pada penelitian tersebut didapatan hasil yaitu adanya peningkatan keaktifan belajar pada siswa, hal tersebut terlihat pada siklus I persentase keaktifan siswa adalah $74,72 \%$ dengan kriteria cukup aktif. Kemudian setelah dilaksanakan siklus II meningkat menjadi $88,28 \%$ dengan kriteria aktif.

\section{PENUTUP}

Berdasarkan pembahasan hasil penelitian, maka dapat disimpulkan bahwa terdapat perbedaan yang signifikan antara kemampuan berpikir kritis siswa pada mata pelajaran PKn antara kelompok siswa yang dibelajarkan menggunakan pembelajaran kooperatif tipe investigasi kelompok dengan kelompok siswa yang diajar dengan model pembelajaran konvensional. Rata-rata kemampuan berpikir kelompok eksperimen 26,90 sedangkan kelompok kontrol 16,73. Hal ini menunjukkan kemampuan berpikiri kritis siswa dikelompok eksperimen lebih baik dibanding kelompok kontrol. Hasil analisisnya menunjukkan $t_{\text {nitung }}=13,20$ dan $t_{\text {tabel }}=2,00$ untuk $d b=n 1+n 2-2=58$ dengan taraf signifikansi $5 \%$. Berdasarkan kriteria pengujian, karena $t$ hitung $>t_{\text {tabel }}$ maka $\mathrm{H}_{0}$ ditolak dan $\mathrm{Ha}$ diterima. Berarti ada pengaruh pembelajaran kooperatif tipe investigasi kelompok terhadap kemampuan berpikir kritis pada mata pelajaran PKn siswa kelas XI SMAN 1 Singaraja

Saran yang disampaikan dalam tulisan ini adalah: (1) kepada siswa, dalam mengikuti setiap kegiatan pembelajaran $\mathrm{PKn}$ lebih aktif sehingga dapat menumbuhkan kemampuan berpikir kritis karena mata pelajaran PKn menuntut siswa untuk mampu berpikir kritis, (2) kepada guru, khususnya yang mengajar PKn dalam proses pembelajaran agar menggunakan pembelajaran kooperatif tipe investigasi kelompok sebagai salah satu alternatif untuk meningkatkan kemampuan berpikir kritis siswa dan minat siswa saat mengikuti pelajaran PKn, (3) kepada kepala sekolah, diharapkan memotivasi guru-guru untuk menerapka pembelajaran, kooperatif tipe investigasi kelompok karena model ini dapat meningkatkan kemampuan berpikir 
kritis siswa, sehingga menghasilkan output siswa yang lebih baik, khususnya dalam mata pelajaran PKn serta mata pelajaran lain pada umumnya, (4) kepada peneliti lain, agar penelitian ini dapat dijadikan acuan ataupun referensi demi ketuntasan penelitian selanjutnya dan memperhatikan kendala-kendala yang dialami sebagai bahan pertimbangan untuk perbaikan dan menyempurnakan pelaksanaan penelitian.

\section{DAFTAR RUJUKAN}

Arsjad, Mukti. 1991. Menguak Rahasia Berpikir Kritis dan Kreatif. Jakarta: PT Prestasi Pustakaraya.

Endang, 2002. Belajar dengan Pendekatan PAILKEM. Cetakan Pertama. Jakarta: PT Bumi Aksara.

Gestalt, Riyanto 2010. Impementasi Paikem dari Behavioristik Sampai Konstruktivistik. Jakarta: Prestasi Pustakaraya.

Roestiyah, Nabisi, dkk. 2008. Belajar dan Pembelajaran SD 2 SKS. Derektorat Jendral Pendidikan Tinggi: Departemen Pendidikan Nasional.

Slameto Riyanto. 2010. Belajar dan Pembelajaran. Singaraja: Institut Keguruan dan Ilmu Pendidikan.

Soli 2. 2009. Metode Penelitian Pendidikan. Bandung: CV Alfabeta.

Keller, Zulfarisma, dkk. 2009. Kajian IPS $S D \quad 3 \quad S K S$. Derektorat Jendral Pendidikan Tinggi Kementrian Pendidikan Nasional.

\section{UCAPAN TERIMAKASIH}

Terimaksi diucapkan kepada Drs. Made Suarjana selaku pembimbing I dan I Nyoman Arcana, SST., M.Pd selaku pembimbing II yang telah memberi banyak masukan serta motivasi terhadapat pembuatan artikel. Drs. Dewa Bagus Sanjaya, Msi terhadap saran-saran yang telah diberikan dalam penyelesaian artikel ini

Utami, 2011. Pengaruh Media Pembelajaran Video Interaktif Berbasis Materi dan Berita Terhadap Kemampuan Berpikir Kritis Siswa Dalam Mata Pelakaran PKn Kelas XI

Undang-undang Republik Indonesia No. 20 Tahun 2003 Tentang sistem Pendidikan Nasional. Tersedia pada http://www.unpad.ac.id/wpcontent/upl oads/2012/10/UU20-2003

Sisdiknas.pdf (diakases tanggal 2 Mei 2013).

Zulfarisma, Muhammad. 2009. Pembelajaran Berbasis Multiple Intellegences. 